\title{
Kepuasan Pasien Ditinjau dari Komunikasi Perawat- Pasien
}

\author{
Maya Khairani', Desi Salviana1, Abu Bakar ${ }^{2}$ \\ 1Program Studi Psikologi Fakultas Kedokteran Universitas Syiah Kuala, Banda Aceh \\ 2Fakultas Keguruan dan Ilmu Pendidikan Universitas Syiah Kuala, Banda Aceh
}

\section{DOI: http://doi.org/10.29080/jpp.v12i1.520}

\begin{abstract}
Patient satisfaction as an important aspect of health care is often viewed from various aspects. This research aims to study a correlation between nurse communication and patient satisfaction.There are 95 hospitalized patients at Hospital X invloved in this research. Data were collected through the Nurse-Patient Communication Scale and the Patient Satisfaction Scale. The results of data analysis using the Pearson correlation indicate that there is a positive and significant relationship between nurse-patient communication and patient satisfaction. In other words, effective communication by nurses to patients will increase patient satisfaction. This research has implications for a hospital organizational culture that promotes effective communication both between fellow health workers and patients.
\end{abstract}

Keywords : patient satisfaction, communication, nurse-patient communication

\begin{abstract}
Abstrak : Kepuasan pasien sebagai salah satu aspek penting dalam pelayanan kesehatan seringkali dilihat dari berbagai aspek. Penelitian ini bertujuan untuk mengetahui hubungan antara komunikasi perawat dengan kepuasan pasien. Sejumlah 95 pasien rawat inap di Rumah Sakit X menjadi responden dalam penelitian ini. Data dikumpulkan melalui Skala Komunikasi Perawat-Pasien dan Skala Kepuasan Pasien. Hasil analisis data dengan menggunakan korelasi pearson menunjukkan bahwa terdapat hubungan yang positif dan signifikan antara komunikasi perawat-pasien dengan kepuasan pasien. Dengan kata lain komunikasi efektif yang dilakukan oleh perawat terhadap pasien akan meningkatkan kepuasan para pasien. Penelitian ini berimplikasi pada budaya organisasi rumah sakit yang mengedepankan komunikasi efektif baik antar sesama tenaga kesehatan maupun dengan para pasien.
\end{abstract}

Kata kunci : kepuasan pasien, komunikasi, komunikasi perawat-pasien

\section{Pendahuluan}

Kepuasan pasien dapat dimaknai sebagai serangkaian evaluasi terhadap intervensi medis pada masalah kesehatan yang dihadapi pasien (Worthington, 2005). Menyinggung

Corresponding Author: Maya Khairani (e-mail: khairani.maya@unsyiah.ac.id) Program Studi Psikologi Fakultas Kedokteran Universitas Syiah Kuala Banda Aceh, Jl. Teuku Nyak Arief No.441 Kota Banda Aceh, Aceh, Indonesia 23111 
kepuasan pasien, maka hal ini terkait harapan atau keinginan pasien dalam menerima pelayanan medis (Siregar, 2016). Kepuasan erat kaitannya dengan emosi yang dirasakan seseorang setelah dirinya membandingkan antara apa yang dipersepsikan atau dipikirkan terhadap kinerja atau hasil suatu produk atau jasa (Siregar, 2016). Pelayanan yang baik dari perawat sangat memengaruhi kualitas pelayanan kesehatan, bahkan dapat menentukan citra rumah sakit di mata masyarakat. Kemampuan perawat dalam berkomunikasi dengan baik menjadi jaminan atau penentu puas tidaknya pasien dalam menerima pelayanan yang diberikan (Muhith \& Nasir, 2011).

Beberapa penelitian menemukan bahwa kepuasan pasien bergantung kepada cara tenaga kesehatan (baik dokter, perawat, dsb) berkomunikasi dengan pasien (Kusumo, 2017; Siti, Zulpahiyana, \& Indrayana, 2016). Pasien merasa sangat puas atas pelayanan yang diberikan oleh perawat bila ditinjau dari respon dan empati perawat ketika berinteraksi dengan pasien (Carlita, 2011; Salman, 2010). Komunikasi interpersonal yang dilakukan oleh perawat sangat efektif dalam usaha penyembuhan pasien. Tujuan komunikasi interpersonal antara lain membantu pasien dalam memperjelas dan mengurangi beban perasaan dan pikiran, serta dapat mengambil tindakan yang efektif untuk pasien (Nugroho, 2009; Sudahri, 2012). Dalam proses komunikasi apabila perawat tidak menunjukkan komunikasi yang baik saat berinteraksi dengan pasien, maka akan menghasilkan respon ketidakpuasan dari pasien (Hanafi \& Richard, 2012).

Kepuasan pasien merupakan sikap pasien terhadap pelayanan yang diberikan oleh rumah sakit dan biasanya dijadikan indikator dalam menilai kualitas pelayanan rumah sakit (Prakash, 2010). Pasien yang merasa tidak puas dengan komunikasi yang ditunjukkan oleh perawat akan menolak terhadap seluruh tindakan keperawatan yang diberikan Pasien tentu memiliki berbagai harapan saat memperoleh layanan kesehatan, salah satunya melalui komunikasi yang efektif dengan tenaga kesehatan. Komunikasi buruk yang diberikan oleh tenaga kesehatan tentunya dapat mengarah pada rasa tidak puas pasien. Secara praktis penelitian terkait kepuasan pasien telah banyak dilakukan pada beberapa dekade terakhir dengan berbagai variasi pengukuran. Namun variable komunikasi masih memerlukan penelitian lebih lanjut karena melibatkan banyak pihak tenaga kesehatan yang ada di sebuah rumah sakit. Selain itu kajian kepuasan pasien bersifat praktis dan berorientasi pada masalah (Worthington, 2005) sehingga membutuhkan pembaharuan data yang lebih cepat.

Anjaswarni (2016) menjelaskan bahwa perawat perlu menunjukkan dua sikap saat menjalin komunikasi dengan pasien yaitu sikap fisik dan psikologis. Secara fisik, perawat idealnya dapat duduk berhadapan, mempertahankan kontak mata saat berbicara, membungkuk ke arah pasien, mempertahankan sikap terbuka, dan rileks. Secara psikologis ada dua dimensi komuniksi yaitu dimensi respon (ikhlas, respek, empati, dan konkret) dan dimensi tindakan (konfrontasi, kesegeraan, terbuka, katarsis emosional, dan bermain peran) yang harus diterapkan dalam konteks kehangatan, penerimaan, dan pengertian.

Komunikasi menjadi hal mendasar yang dibutuhkan dalam pelayanan kesehatan (Khairani, 2011). Kemampuan untuk berkomunikasi interpersonal dianggap sebagai hal penting dalam keberhasilan seseorang menjalankan tugas profesionalnya dan membawa keuntungan sendiri pada praktik kesehatan, seperti mengurangi kemungkinan malpraktik. Komunikasi interpersonal dapat dimaknai sebagai interaksi verbal dan nonverbal antara dua atau bisa lebih dari dua orang yang saling bergantung (Devito, 2013). Pada praktiknya komunikasi interpersonal dapat terjadi antara ayah dengan anak, guru dengan murid, dua orang sahabat, hingga antara penyedia layanan kesehatan (dokter, dokter gigi, perawat, dsb) dengan pasiennya.

Salah satu bentuk komunikasi interpersonal dalam dunia kesehatan adalah komunikasi yang terjalin antara perawat dan pasien. Komunikasi perawat-pasien merupakan hubungan kerjasama yang ditandai dengan tukar menukar perilaku, pikiran, 
perasaan, dan pengalaman dalam membina hubungan yang harmonis dengan pasien (Mulyana, 2001). Komunikasi ini juga disebut komunikasi terapeutik karena dilakukan secara sadar, memiliki tujuan untuk membantu proses pemulihan pasien, dimana perawat diposisikan sebagai pihak yang memberi bantuan dan pasien merupakan penerima bantuan (Anjaswarni, 2016; Siti, Zulpahiyana, \& Indrayana, 2016). Perawat memiliki kewajiban untuk selalu sadar bahwa tugas profesinya berhubungan dengan orang-orang sakit dan secara sosial sangat membutuhkan pertolongan (Purba, 2003). Perawat dapat menjadi obat pertama bagi pasien dengan tutur kata yang lembut, senyum penuh ketulusan, sikap akrab, dan memotivasi pasien untuk sembuh (Siregar, 2016).

Siregar (2016) mengutarakan bahwa penggunaan komunikasi yang baik antara tenaga kesehatan dan pasien mempunyai peranan penting dalam menjalankan tugas pelayanan kesehatan. Menurut Anjaryani (2009) perawat berperan untuk memberikan motivasi kepada pasien, mendengarkan keluhan pasien, menghibur dan memberikan semangat kepada pasien untuk menjalankan peraturan yang diberikan oleh dokter dan minum obat yang teratur guna penyembuhan pasien.

Menurut Muchlasin (2004) faktor-faktor yang berhubungan dengan kepuasan pasien rawat inap di rumah sakit adalah keramahan perawat, perhatian perawat, kesabaran perawat, ketulusan perawat, dan kesopanan perawat. Pentingnya komunikasi dalam menentukan kepuasan pasien ternyata pada praktiknya masih menemui tantangan pada layanan kesehatan di rumah sakit. Keluhan pasien atau keluarganya sebagai pengguna layanan masih terus berdatangan sehingga pihak rumah sakit merasa perlu berbenah. Selain itu, masih banyaknya masyarakat yang memiliki preferensi melakkan pemeriksaan kesehatan kepada layanan kesehatan di luar negeri dibandingkan di daerahnya sendiri. Kajian tentang hal ini juga masih terus mendapat perhatian dari berbagai disiplin ilmu. Hal ini yang kemudian mendorong peneliti untuk mengungkap kaitan antara komunikasi perawat-pasien dengan kepuasan pasien di Rumah Sakit X.

\section{Metode Penelitian}

Penelitian ini melibatkan 95 pasien rawat inap di Rumah Sakit X dengan kriteria pasien dalam keadaan sadar, menjalani rawat inap minimal dua hari, dan merupakan pasien dewasa dengan rentang usia 20-60 tahun. Data dikumpulkan melalui dua skala yang disusun oleh peneliti, yaitu Skala Komunikasi Perawat-Pasien dan Skala Kepuasan Pasien. Skala Komunikasi Perawat-Pasien disusun berdasarkan aspek-aspek komunikasi interpersonal yaitu keterbukaan, empati, dukungan, sikap positif, dan kesetaraan (Devito, 2013). Skala Kepuasan Pasien disusun berdasarkan dimensi yang menurut Parasuraman dan Berry (dalam Siregar, 2016) harus ada dalam kegiatan pelayanan yang dapat memberi kepuasan kepada pelanggan dalam hal ini pasien. Adapun dimensi yang dimaksud adalah bukti fisik, kehandalan, ketanggapan, jaminan dan kepastian, dan empati (Nursalam, 2011; Siregar, 2016).

Setiap pernyataan dalam dua skala tersebut terdiri dari pernyataan yang bersifat favorabel dan unfavorable dengan lima alternatif pilihan jawaban yaitu Sangat Sesuai (SS), Sesuai (S), Netral (N), Tidak Sesuai (TS), dan Sangat Tidak Sesuai (STS). Sistem penilaian bergerak dari nilai 1 sampai 5 tergantung pada sifat pernyataan. Teknik analisis data yang digunakan dalam penelitian ini adalah korelasi product moment dari Pearson, dan keseluruhan analisa data dilakukan dengan bantuan aplikasi statistic.

\section{Hasil Penelitian}

Berdasarkan data yang diperoleh, peneliti menganalisa secara deskriptif data dari dua skala sehingga terdapat perbandingan antara hasil penelitian hipotetik dan hasil penelitian empiris. Deskripsi data ini dapat dilihat pada tabel 1. 
Tabel 1

Deskripsi Data Penelitian

\begin{tabular}{lcccccccc}
\hline \multirow{2}{*}{ Variabel } & \multicolumn{4}{c}{ Data Hipotetik } & \multicolumn{5}{c}{ Data Empirik } \\
\cline { 2 - 8 } & Xmaks & Xmin & Mean & SD & Xmaks & Xmin & Mean & SD \\
\hline $\begin{array}{l}\text { Komunikasi } \\
\begin{array}{l}\text { Perawat- } \\
\text { Pasien }\end{array}\end{array}$ & 150 & 30 & 90 & 20 & 142 & 90 & 125.03 & 8.324 \\
\hline $\begin{array}{l}\text { Kepuasan } \\
\text { Pasien }\end{array}$ & 150 & 30 & 90 & 20 & 135 & 84 & 116.40 & 5.983 \\
\hline
\end{tabular}

Mengacu pada perbandingan data deskriptif pada tabel 1, diperoleh bahwa nilai mean empirik komunikasi perawat-pasien lebih besar daripada mean hipotetik yaitu 125.03 > 90. Hal itu menunjukkan bahwa komunikasi perawat-pasien pada subjek penelitian ini lebih tinggi daripada populasi pada umumnya. Data kedua adalah nilai mean empirik kepuasan pasien juga lebih besar jika dibandingkan dengan mean hipotetik yaitu $116.40>90$. Dengan kata lain mayoritas kepuasan pasien yang menjadi sunjek penelitian ini adalah lebih tinggi daripada populasi pada umumnya.

Selanjutnya nilai rerata (mean) pada data empirik digunakan untuk mengetahui kecenderungan respon responden terhadap tiap-tiap variabel penelitian yang dapat dijadikan batasan dalam pengkategorian data dari responden. Adapun rumus untuk pengkategorian ditampilkan pada tabel 2 .

Tabel 2

Norma Kategorisasi Variabel Penelitian

\begin{tabular}{cl}
\hline Kategori & \multicolumn{1}{c}{ Rumus Kategori } \\
\hline Tinggi & $\mathrm{M}+1.0 \mathrm{SD} \leq \mathrm{X}$ \\
Sedang & $\mathrm{M}-1.0 \mathrm{SD} \leq \mathrm{X}<\mathrm{M}+1.0 \mathrm{SD} \leq \mathrm{X}$ \\
Rendah & $\mathrm{X}<\mathrm{M}-1.0 \mathrm{SD}$ \\
\hline
\end{tabular}

Berpedoman pada norma pada tabel 2, peneliti melakukan kategorisasi skor tiaptiap responden penelitian pada masing-masing variabel penelitian. Hasil kategorisasi komunikasi perawat-pasien dapat dilihat pada tabel 3 yang menunjukkan bahwa mayoritas responden merasakan komunikasi perawat-pasien ada pada pada kategori sedang yaitu sebanyak 72 pasien (76\%). Adapun kategori kepuasan pasien yang dialami responden paling banyak berada pada kategori sedang dengan 76 responden $(80 \%)$.

Tabel 3

Kategorisasi Respon

\begin{tabular}{ccc}
\hline Kategori & Komunikasi perawat-pasien & Kepuasan pasien \\
\hline Tinggi & $16(17 \%)$ & $15(15,8 \%)$ \\
Sedang & $72(76 \%)$ & $76(80 \%)$ \\
Rendah & $7(7 \%)$ & $4(4,2 \%)$ \\
\hline
\end{tabular}

Berdasarkan uji normalitas yang dilakukan pada data 95 sampel untuk variabel komunikasi perawat-pasien memiliki sebaran yang normal ( $\mathrm{K}-\mathrm{S}-\mathrm{Z}=0.528$ dengan $\mathrm{p}>0.05)$. Selanjutnya data variabel kepuasan pasien juga memiliki sebaran normal (K-S-Z $=0.099$ dengan $\mathrm{p}>0.05$ ). Hasil uji linearitas diperoleh nilai signifikansi pada linearitas sebesar 0.000 , signifikansi kecil dari $0.05(0.000<0.05)$. Dengan kata lain terdapat hubungan yang linear antara variabel komunikasi perawat-pasien dan variabel kepuasan pasien.

Analisis korelasi Pearson menunjukkan hasil korelasi sebesar $r=0.640$ ( $r_{\text {hitung }}>$ $\left.r_{\text {tabel }}=0.263\right)$ dengan tingkat signifikansi $p=0.000(p<0.01)$. Hasil tersebut menunjukkan bahwa terdapat hubungan positif dan signifikan antara kedua variabel. Hasil tersebut dapat diinterpretasikan bahwa semakin efektif komunikasi antara perawat dan pasien 
maka semakin tinggi kepuasan yang dirasakan para pasien. Sebaliknya jika komunikasi antara perawat dan pasien tidak efektif maka semakin rendah pula kepuasan pasien. Dengan demikian penelitian menunjukkan ada hubungan positif dan signifikan antara komunikasi perawat-pasien dengan kepuasan pasien di Rumah Sakit X.

Selain melihat hubungan antara komunikasi perawat-pasien dengan kepuasan pasien, analisis per aspek pada variabel penelitian juga dilakukan. Tujuan dari analisis lanjutan ini adalah untuk melihat aspek mana yang sangat berhubungan dengan variabel kepuasan pasien.

Tabel 4

Deskripsi Data Penelitian

\begin{tabular}{lcc}
\hline $\begin{array}{c}\text { Aspek dari Variabel Komunikasi } \\
\text { Perawat-Pasien }\end{array}$ & $\begin{array}{c}\text { Korelasi dengan Variabel } \\
\text { Kepuasan Pasien }\end{array}$ & Signifikansi \\
\hline Keterbukaan & 0.524 & $\mathrm{p}<0.01$ \\
Empati & 0.633 & $\mathrm{p}<0.01$ \\
Dukungan & 0.462 & $\mathrm{p}<0.01$ \\
Sikap positif & 0.552 & $\mathrm{p}<0.01$ \\
Kesetaraan & 0.563 & $\mathrm{p}<0.01$ \\
\hline
\end{tabular}

Tabel 4 menunjukkan bahwa ada lima aspek dalam variabel komunikasi yang dilakukan antara perawat dan pasien. Meskipun semua aspek menunjukkan nilai signifikansi, namun aspek empati memiliki hubungan yang paling kuat dibandingkan dengan empat aspek lainnya. Selanjutnya kesetaraan, sikap positif, keterbukaan, serta terakhir adalah dukungan yang diberikan merupakan aspek yang juga berhubungan dengan kepuasan yang dirasakan pasien.

\section{Pembahasan}

Analisis korelasi menunjukkan bahwa komunikasi perawat-pasien merupakan salah satu faktor yang berhubungan kuat dan signifikat dengan kepuasan pasien di Rumah Sakit X. Hasil penelitian ini selaras dengan hasil penelitian-penelitian sebelumnya yang juga menemukan bahwa komunikasi yang efektif yang diberikan oleh tenaga kesehatan dapat meningkatkan kepuasan pada pasien (Khotimah, Marsito, \& Iswati, 2012). Komunikasi interpersonal yang sehat menimbulkan terjadinya pemecahan masalah, berbagi ide atau pengalaman, pengambilan keputusan, dan perkembangan pribadi (Asrin, Diana, \& Wahyu, 2006). Selain itu, komunikasi yang efektif dipercaya dapat meningkatkan kepercayaan pasien terhadap penyedia layanan kesehatan dan menurunkan kecemasan pasien (Khairani, 2011).

Penelitian ini juga semakin memperkuat beberapa penelitian sebelumnya yang mengatakan bahwa terdapat hubungan yang bermakna antara komunikasi perawatpasien dengan kepuasan pasien. Perawat dapat memberikan kepuasan bagi pasien salah satunya dengan cara berkomunikasi secara efektif (Dewi, 2012) dan terapeutik (Khotimah, Marsito, \& Iswati, 2012; Kusumo, 2017; Siregar, 2016; Siti, Zulpahiyana, \& Indrayana, 2016). Hubungan interpersonal yang hangat antara perawat dan pasien ditandai dengan sikap keterbukaan, saling percaya, menerima, dan menghargai (Samikaryani, 2009). Perawat juga harus mampu memberikan kenyamanan bagi pasien, memberi dukungan penuh pada semua yang dilakukan pasien sehingga berdampak positif bagi kesembuhan pasien (Rakhmad, 2005; Dewi, 2012).

Hanafi dan Richard (2012) juga mengungkapkan bahwa dalam upaya meningkatkan kepuasan pasien, rumah sakit harus memberikan pelayanan yang terbaik, terutama dalam bidang keperawatan. Perawat atau tenaga kesehatan di rumah sakit harus memiliki kemampuan komunikasi yang baik khususnya komunikasi interpersonal. Pasien secara langsung maupun tidak langsung akan menilai kinerja perawat dari interaksi yang 
terjalin antara perawat dan pasien ketika menjalani perawatan di rumah sakit. Selanjutnya apa yang mereka rasakan akan berdampak terhadap tingkat kepuasan pasien.

Komunikasi interpersonal adalah inti dari praktik keperawatan. Terciptanya kepuasan pasien dapat memberikan beberapa manfaat, diantaranya hubungan antara rumah sakit atau tenaga kesehatan dengan pengguna jasa kesehatan menjadi harmonis. Selain itu kepuasan pasien akan menjadi dasar yang baik bagi pengguna jasa kesehatan untuk kembali lagi ke rumah sakit tersebut sehingga tercipta loyalitas pengguna jasa kesehatan. Pada umumnya rekomendasi dari mulut ke mulut lebih menguntungkan bagi rumah sakit, dan meningkatkan reputasi rumah sakit menjadi lebih baik di mata pengguna jasa kesehatan (Andri, 2011).

Wright (2012) menyatakan bahwa jika pasien merasa puas, maka akan memudahkan perawat atau tenaga kesehatan lainnya dalam melakukan tindakan perawatan. Pasien akan mengikuti saran dan instruksi dari tenaga kesehatan, dan akan mudah untuk menumbuhkan pemahaman yang lebih baik kepada pasien tentang informasi pengobatan medis.

Uji analisis data yang melihat hubungan per aspek dari komunikasi perawatpasien juga menunjukkan urutan aspek yang sangat berperan dalam menciptakan kepuasan pada pasien. Kelima aspe dari komunikasi yang terdiri dri keterbukaan, empati, dukungan, sikap positif, dan kesetaraan memiliki korelasi positif dan signifikan dengan kepuasan pasien. Namun aspek yang memiliki korelasi paling tinggi terhadap kepuasan pasien adalah empati. Empati memiliki peranan yang besar dalam meningkatkan kepuasan pasien, seperti kemampuan perawat dalam memberikan perhatian, keramahan perawat, dan perawat mendengarkan keluhan maupun harapan pasien. Pasien akan merasa puas terhadap pelayanan dari perawat jika perawat mampu memperhatikan kebutuhan pasien, serta mampu memberikan informasi kesehatan sesuai dengan keluhan pasien (Hanafi \& Richard, 2012; Utama, 2004; Prakash, 2010).

Kunci dari komunikasi yang efektif dalam hubungan perawat-pasien adalah menunjukkan empati (Kliszcz, Nowak, Sadowska, Sauer, \& Trzeciak, 2006). Rasa empati akan menimbulkan penghargaan atau respek yang dapat membangun kepercayaan dan keterbukaan yang diperlukan dalam membangun kerjasama sehingga memudahkan perawat dalam memberikan asuhan keperawatan (Mubarak, Muhith, Nasir, \& Sajidin, 2011). Aspek kesetaraan menduduki posisi kedua sebagai aspek yang memiliki hubungan positif dan signifikan dengan kepuasan pasien. Wahdi (2006) menyatakan bahwa kesetaraan merupakan keinginan yang secara tidak langsung diungkapkan untuk bekerjasama dalam memecahkan masalah pasien. Kesetaraan menyiratkan adanya sikap perawat memperlakukan pasien secara sejajar atau sama tanpa perbedaan.

Sikap positif merupakan aspek komunikasi ketiga yang memiliki korelasi dengan kepuasan pasien. Hal ini menunjukkan bahwa sikap positif memiliki hubungan yang signifikan dengan kepuasan pasien. Caring atau perhatian dapat disebut sebagai salah satu bentuk sikap positif yang dapat ditunjukkan oleh perawat kepada pasien yang dapat menyebabkan munculnya kepuasan pasien dalam proses perawatan (Ilkafah \& Harniah, 2017; Soviarni). Aspek keterbukaan memiliki korelasi yang positif dan signifikan dengan kepuasan pasien di Rumah Sakit X. Husna, Sumarliyah, dan Tipo (2009) menyatakan bahwa keterbukaan antara perawat dan pasien, kejujuran dalam memberikan informasi, dan menerima keadaan pasien akan meningkatkan kemampuan pasien dalam membina hubungan yang saling percaya dengan perawat.

Aspek terakhir yang juga berhubungan dengan kepuasan pasien adalah dukungan yang diberikan para tenanga kesehatan selama pasien berada di rumah sakit. Korelasi aspek dukungan dengan kepuasan pasien terlihat paling rendah dibandingkan dengan aspek lainnya. Ada beberapa hal yang dapat menjadi alasan seperti tenaga kesehatan yang ada di rumah sakit tidak memiliki sumber-sumber informasi yang dibutuhkan pasien. 
Selain itu mereka juga bisa sedang berada dalam kondisi stres bahkan membutuhkan bantuan, serta tidak cukup sensitif terhadap pasien yang dihadapi (Sarafino, 1997).

Kepuasan yang dirasakan pasien tampaknya juga ada kontribusi dari pihak pasien sendiri seperti kurang asertif untuk meminta bantuan dan merasa tidak seharusnya membebani orang lain. Mereka juga merasa enggan mempercayakan sesuatu kepada orang lain, atau tidak tahu cara menyampaikan bahwa dirinya membutuhkan pertolongan. Dukungan keluarga juga mempunyai andil besar dalam proses pemulihan meskipun hanya dalam bentuk dukungan emosional. Kasih sayang, perhatian dan mendengarkan dengan simpatik merupakan contoh dukungan emosional selain fasilitas materi seperti penyediaan dana (Pangastiti, 2011; Wurtiningsih, 2012).

Hasil penelitian menunjukkan bahwa sumbangan komunikasi perawat-pasien terhadap kepuasan pasien adalah sebesar $40 \%$, sementara $60 \%$ dipengaruhi oleh variabel lain yang tidak terlibat dalam penelitian ini. Menurut Wahdi (2006) variabel lain yang berhubungan dengan kepuasan pasien adalah dimensi mutu pelayanan. Mutu pelayanan dapat mencakup efisiensi pelayanan, perhatian, keterampilan dan pengetahuan ilmiah yang dimiliki tenaga kesehatan serta kenyamanan pelayanan yang dirasakan pasien.

\section{Simpulan dan Saran}

Hubungan positif dan signifikan antara komunikasi perawat-pasien dengan kepuasan pasien menunjukkan bahwa komunikasi yang efektif akan meningkatkan kepuasan pada diri pasien. Mayoritas pasien secara kategori berada pada kelompok kepuasan sedang serta tingkat komunikasi yang sedang juga. Lima aspek dalam komunikasi memiliki hubungan yang signifikan terhadap kepuasan pasien yaitu aspek empati, kesetaraan, sikap positif, keterbukaan, dan dukungan. Tidak adanya sumber informasi yang dibutuhkan pasien, kondisi stress yang dialami, serta kurang sensitif terhadap pasien yang dihadapi merupakan sejumlah alasan mengapa aspek dukungan memiliki nilai yang paling rendah.

Sejumlah keterbatasan penelitian ini dapat menjadi celah bagi penelitian selanjutnya seperti jumlah pernyataan yang terlalu banyak sehingga responden kesulitan dalam mengisi karena kondisi kesehatan yang berbeda-beda. Selain itu data yang diambil adalah data shift pagi dan sore sehingga tidak dapat memotret kondisi pada malam hari. Klasifikasi kelas atau ruangan pasien (kelas I, II, III, VIP) saat pengambilan data juga tidak menjadi perhatian dalam penelitian ini sehingga tidak dapat melihat lebih jauh perbedaan pelayanan pada setiap kelas.

\section{Daftar Pustaka}

Andri, G. (2011). Pengaruh kinerja pelayanan RS Islam Ibnu Sina dan Kepuasan pasien sebagai variabel moderator terhadap loyalitas pasien pada RS Islam Ibnu Sina di Sumatera Barat. Jurnal Manajemen dan Kewirausahaan, 2 (2), 58.

Anjaryani, W. D. (2009). Kepuasan pasien RSUD Tugurejo Semarang. Tesis. Semarang: Program Pascasarjana Universitas Diponegoro. Diakses 20 maret 2012 melalui http:/ejournal.unud.ac.id

Anjaswarni, T. (2016). Komunikasi dalam Keperawatan. Kementerian Kesehatan Republik Indonesia.

Asrin, Diana, R.S., \& Wahyu, E. (2006). Hubungan Pengetahuan Komunikasi Terapeutik terhadap Kemampuan Komunikasi Perawat dalam Melaksanakan Asuhan Keperawatan di Rumah Sakit Elisabeth Purwokerto. Jurnal Keperawatan Soedirman, 1 (2).

Carlita, T. (2011). Hubungan antara Kualitas Komunikasi Interpersonal Petugas Medis dan Pasien Rawat Inap dengan Tingkat Kepuasan Komunikasi Pasien (Kasus di Rumah 
Sakit Bethesda). Abstrak Tesis. Yogyakarta: Universitas Atma Jaya. Diakses tanggal $15 \quad$ Mei $2013 \quad$ melalui

http://adl.aptik.or.id/default.aspx?tabID $=61 \&$ src $=k \& i d=570154$

Devito, J. A. (2013). The Interpersonal Communication Book $13^{\text {th }}$ edition. New Jersey: Pearson Edcation Inc.

Dewi, M. (2012). Pengaruh Pelatihan Timbang Terima Pasien terhadap Penerapan Keselamatan Pasien oleh Perawat Pelaksana di RSUD Raden Mattaher Jambi. Jurnal Health \& Sport, 5 (3).

Hanafi, I., \& Richard, S.D. (2012). Keterampilan Komunikasi Interpersonal Perawat Berpengaruh pada Peningkatan Kepuasan Pasien. Jurnal STIKES, 5 (2).

Husna, A., Sumarliyah, E., \& Tipo, A. 2009. Hubungan Komunikasi Terapeutik Perawat dengan Kepuasan Pasien dalam Pelayanan Keperawatan di Rumah Sakit Siti Khodijah Sepanjang. Skripsi. Universitas Muhammadyah Surabaya. Diakses 19 Juni 2013.

Ilkafah., \& Harniah. (2017). Perilaku caring perawat dengan kepuasan pasien di Ruang Rawat Inap Private Care Centre RSUP Dr Wahidin Sudirohusodo Makassar. Jurnal Keperawatan, Vol. 8 No. 2. DOI: https://doi.org/10.22219/jk.v8i2\%20Juli.4034

Khotimah, N., Marsito., \& Iswati, N. (2012). Hubungan komunikasi terapeutik perawat dengan kepuasan pelayanan keperawatan di Ruang Inayah Rumah Sakit PKU Muhammadiyah Gombong. Jurnal Ilmiah Kesehatan Keperawatan, 8 (2): 73-80.

Khairani, M. (2011). The Role of Empathic Services Program for Dentist/Dental Nurse in Improving Communication Skills with Dental Patients in Public Health Center. Proceeding of PICP-Padjadjaran International Conference on Psychology.

Kliszcz, J., Nowicka-Sauer, K., Trzeciak, B., Nowak, P., \& Sadowska, A. (2006). Empathy in health care providers-validation study of the Polish version of the Jefferson Scale of Empathy. Advances in Medical Sciences, 51, 219-225.

Kusumo, M. P. (2017). Pengaruh komunikasi terapeutik perawat terhadap kepuasan pasien di Rawat Jalan RSUD Jogja. Jurnal Medicoeticolegal dan Manajemen Rumah Sakit, 6 (1): 72-81. DOI: 10.18196/jmmr.6130

Mubarak, W.I., Muhith, A., Nasir, A., \& Sajidin, M. (2011). Komunikasi dalam Keperawatan: Teori dan Aplikasi. Jakarta: Salemba Medika.

Muchlasin. (2004). Analisis Pengaruh Kompetensi Interpersonal Perawat Terhadap Persepsi Kepuasan Pasien Rawat Inap RSUD Batang. Abstrak Tesis. Semarang: Program Pasca Sarjana Universitas Diponegoro. Diakses tanggal 15 Mei 2013 melalui http://eprints.undip.ac.id/14668/

Muhith, A., \& Nasir, A. (2011). Dasar-dasar Keperawatan Jiwa. Jakarta: Salemba Medika.

Mulyana, D. (2001). Ilmu Komunikasi: Suatu Pengantar. Bandung: Rosda.

Nursalam. (2011). Manajemen Keperawatan. Jakarta: Salemba Medika.

Nugroho, A.W. (2009). Komunikasi Interpersonal antara Perawat dan Pasien (Studi deskriptif kualitatif aktivitas komunikasi terapeutik antara perawat terhadap pasien di rumah sakit umum daerah dr. moewardi). Abstrak Skripsi. Surakarta: Universitas Sebelas Maret. Diakses tanggal 15 Mei 2013 melalui http:// dglib.uns.ac.id/pengguna.php? $\mathrm{mn}=$ showview\&id $=14430$

Pangastiti, N. K. (2011). Analisis Pengaruh Dukungan Sosial Keluarga terhadap Burnout pada Perawat Kesehatan di Rumah Sakit Jiwa. Skripsi. Semarang: Universitas Diponegoro. $\quad$ Diakses $23 \quad$ Mei $2013 \quad$ melalui http://www.eprints.undip.ac.id/29408/1/skripsi008.pdf.

Prakash B. (2010). Patient satisfaction. Journal of cutaneous and aesthetic surgery, 3(3), 151-155. https://doi.org/10.4103/0974-2077.74491

Purba, J.M. (2003). Komunikasi dalam keperawatan. Jurnal Manajemen Pelayanan Kesehatan, 9 (4), 177-184.

Rakhmad, J. (2005). Psikologi Komunikasi. Edisi Revisi. Bandung: PT Remaja Rosdakarya. 
Salman, N. (2010). Pengaruh Komunikasi Terapeutik Perawat terhadap Kepuasan Pasien di Rumah Sakit Haji Medan. Abstrak Skripsi. Universitas Sumatera Utara. Diakses tanggal $15 \quad$ Mei $2013 \quad$ melalui http://repository.usu.ac.id/handle/123456789/24558

Samikaryani, S. (2009). Hubungan Komunikasi Interpersonal Perawat-Pasien dengan Tingkat Kepuasan Pasien di Ruang Anggrek Rumah Sakit Hospital Cinere. Skripsi. Jakarta: Universitas Pembangunan Veteran. Diakses 27 April 2013.

Sarafino, E. P. (1997). Health Psychology: Biopsychosocial Interactions (3th ed). New York: Wiley.

Siregar, N. S. S. (2016). Komunikasi terapeutik dokter dan paramedis terhadap kepuasan pasien dalam pelayanan kesehatan pada rumah sakit bernuansa islami di kota Medan. Disertasi. Universitas Islam Negeri Sumatera Utara.

Siti, M., Zulpahiyana., \& Indrayana, S. (2016). Komunikasi Terapeutik Perawat Berhubungan dengan Kepuasan Pasien. JNKI, Vol. 4, No. 1, 30-34.

Soviarni. (2019). Hubungan sikap dan perilaku caring perawat terhadap kepuasan pasien di Ruang Rawat Inap Interne RSU Mayjen H.A Thalib Kerinci tahun 2017. Menara Ilmu, XIII No. 5. DOI: https://doi.org/10.33559/mi.v13i5.1365

Sudahri. (2012). Peranan Komunikasi Interpersonal Perawat dalam Upaya Penyembuhan Pasien di Rumah Sakit Elizabeth Situbondo. Abstrak Skripsi. Jember: Universitas Muhammadiyah Jember. Diakses tanggal 15 Mei 2013 melalui http://digilib.unmuhjember.ac.id/gdl.php? mod=browse\&op =read\&id=umj-1xsudahri-8

Utama, F. (2004). Analisis Pelayanan Bedah Sehari ditinjau dari Sisi Harapan dan Kepuasan Pasien di Rumah Sakit Mardi Rahayu Kudus. Tesis. Semarang: Program Pascasarjana Universitas Diponegoro. Diakses 27 April 2013.

Wahdi, N. (2006). Analisis Faktor-faktor yang Mempengaruhi Kepuasan Pasien sebagai Upaya Meningkatkan Loyalitas Pasien. Tesis. Semarang: Program Pascasarjana Universitas Diponegoro. Diakses 6 Mei 2013.

Worthington, C. (2005). Patient satisfaction with health care: Recent theoretical developments and implications for evaluation practice. The Canadian Journal of Program Evaluation Vol. 20 No. 3 Pages 41-63.

Wright, S. (2012). Patient Satisfaction in the Context of Cancer Care. The Irish Journal of Psychology, 19 (2), 274-282.

Wurtiningsih, B. (2012). The Family Support to Stroke Patients in Neurology Ward Dr. Kariadi Hospital Semarang. Medica Hospitalia, 1 (1), 57-59. 